\title{
BRAND-TRUST ENHANCING SALES PROMOTION THROUGH ONLINE SHOPPING
}

\author{
Arsil Imawan, Ayu Ekasari \\ Faculty of Economics and Business, Trisakti University. \\ *Corresponding Author: acilimawan97@gmail.com
}

\author{
ARTICLE INFO \\ Article History: \\ Received: February 21, 2020 \\ Revised: July 09, 2020 \\ Published Online: August 17, 2020 \\ Keywords: \\ Sales Promotion, Online Brand Trust, \\ Online Shopping, Online Retailers, \\ Indonesia \\ How to cite: \\ Imawan, A., Ekasari, A. (2020). \\ Brand-Trust Enhancing Sales \\ Promotion through Online Shopping. \\ International Journal of Digital \\ Entrepreneurship and Business \\ (IDEB), 1(1), $23-29$.
}

\begin{abstract}
The research aims to determine the effects of sales promotion on online shopping moderated by brand trust. Meanwhile, data was directly collected through the distribution of questionnaires to 210 respondents. The sample was obtain using a purposive sampling technique. Furthermore, the hypotheses were tested using SEM analysis (Structural Equation Model). The results confirmed that the influence of sales promotion on shopping is moderated by brand trust. It also confirmed that the brand trust is a variable model that moderates the effect of sales promotion. Therefore, this study has implications for online retail managers in creating trust among consumers.
\end{abstract}

\section{INTRODUCTION}

Current development and technology have encouraged consumers to use the internet as a medium for shopping daily needs. This phenomenon has led to the development of several shopping websites in Indonesia. In fact, it is supported by the increasing number of its users. In 2017, the number of online shop users has a transaction value of IDR 75 trillion. This came from 24.7 million consumers, with a total reaching 132.7 million in early 2017.

Some of the most active and well-known online shops are Blibli.com, Bukalapak, JD.Id, Lazada, Shopee, and Tokopedia. This was identified based on research conducted by Ecommerce IQ in 2017 using 1240 respondents. High competition certainly makes these retail owners create consumer trust in their brand (online brand trust). This can be interpreted as a sense of consumer security, where they feel that a certain brand can meet their expectations.

Based on the description above, online retailers need to understand how trust affects their brand in increasing purchases during sales promotion. Accordingly, they can design their marketing strategies to increase consumer trust. Therefore, this study aimed to analyze the effects of sales promotion on online shopping and brand trust that moderate the relationship between them.

\section{LITRATURE REVIEW}

Soni and Verghese (2018) stated that among the well-known techniques in conducting sales promotions, which are contests, discounts, premiums, rebates, and offers, discounts and offers have more important role in determining purchasing behavior. Meanwhile, appropriate display and clear demarcation between various types of products can influence purchases, as well as help consumers to easily identify 
the name and price of the offered goods.

Furthermore, Alvarez and Casielles (2005) showed that sales promotions influence the purchasing process, where consumers can consider both the benefits and costs of a product. In a subsequent study, they stated that promotions have an impact on consumers' behavior towards certain products or brands which they may be unable to purchase.

Pathak et al, (2010) explained that these activities use all types of approaches to stimulate target consumers and accelerate their intention to purchase certain products or services. Promotion as marketing activities implemented by brands to influence and motivate potential consumers to buy the offered products and services. (Satit et al, 2012: Witel, 2011). Meanwhile, Pourdehghan (2015) stated that this activity is important in attracting attention and creating interest in the product and service of a brand. Therefore, promotion techniques can be described in different forms, such as, price stimulation, free samples, lower prices, and prize draws. These activities play a strong role in attracting potential customers and influence their purchasing behavior. Hence, they are mostly applied by various brands to stimulate and get positive responses from consumers (Kotler \& Keller, 2012).

Hassan et al. (2013) showed that promotions have a significant positive impact on customer purchasing decisions. They also showed these activities play an important role in influencing perceived brand value. Moreover, Witel (2011) stated that loyal customers can enjoy price promotions as well as develop positive perceptions of the brand.

Trust is a very important factor that influences the intention (Pavlou \& Geffen, 2004) to purchase, and also triggers consumers to engage in online shopping. Also, increasing the interaction between customers and brands create experience value, which will results in trust (Zhou, Zhang, Su, \& Zhou, 2012). Meanwhile, previous studies which examined online shopping behavior showed that it is very important for retailers to know the factors that influence users to buy online. It was also shown that customer purchasing decisions depend on brand trust (Soni \& Verghese, 2018).

Liu et al. (2012) argued that trust is an important mediator in consumer behavior before or after product purchase, leading to a long-term relationship between the two parties. Furthermore, it can facilitate buyer-to-seller transactions, and it is considered very important in maintaining the interactions between them (Kenning, 2008). In addition, trust is a mental condition that is based on a person's situation and social context. It is the belief of one party regarding the intention of another.

Trust can be interpreted as customer's expectations of service providers to be reliable in fulfilling their commitments (Siagian \& Cahyono, 2014). Azam (2013) showed that no transaction will occur in online trading without mutual trust between both buyers and sellers. Meanwhile, Winch and Joyce (2006) stated it as a reference for internet-based transactions. Therefore, e-trust is very important for the growth of e-commerce (Wang \& Hu, 2009), and it does not appear instantly but needs to be built in stages (Hendrata et al., 2013). In addition, Hsiao et al. (2010) defined it as consumers' willingness to trust certain sites.

Online shopping refers to the process of inquiry and purchase of a product or service via the internet. In general, it is a process of selling and buying goods or services on the World Wide Web. Also, Gong and Maddox (2011) observed that some researches were conducted, which are related to the five stages of the Engel, Kollet and Blackwell model, i.e., the need or recognition of problems, information seeking, alternative evaluations, purchasing decisions, and post-purchase behavior. However, there is no agreement on the application of the consumer behavior model to the online purchasing scenario.

Soni and Verghese (2018) showed that online shopping provides tremendous benefits for customers, hence it spreads rapidly throughout the world market. Also, the sellers make sales by sending wares to the buyer's house where they can buy as many items as they want. Therefore, e-commerce simply refers 
to trade that takes place via the internet, where buyers visit the seller's website and make product payments online. The goods are then delivered physically to the consumers (Yulihasri et al., 2011). Meanwhile, Smith and Rupp (2003) stated that security information needs to be considered to make consumers feel safe and comfortable.

Gallagher et al. (2001) stated that online networks provide various promotional mechanisms that positively influence purchases. These sales promotions include a variety of tools designed to stimulate stronger market responses. Meanwhile, Soni and Verghese (2018) stated that among the well-known techniques, such as contests, discounts, premiums, rebates, and offers, discounts and offers have more important role in determining purchasing behavior.

Also, Dawson and Kim (2009) showed that consumer perceive online shopping to be more convenient. In fact, they argued that conventional shopping is accompanied by anxiety, discomfort, and limited time. With online shopping offers, consumers can easily make effective and efficient transactions at the comfort of their homes (Momtaz et al., 2011). Therefore, it can be concluded that sales promotion has a positive influence on online shopping.

Pourdehghan (2015) affirmed that promotion is important for attracting consumers attention and also created their interest in a particular product or brand. Online retail provides various sales promotion projects such as gifts, discounts, etc., which stimulate customer responses. Chandon et al. (2000) explained that promotion is considered to have functional impacts and benefits in terms of quality and cost advantage. Based on the statement above, it can be concluded that the influence of sales promotion and online shopping on consumers is strengthened by the brand trust.

\section{METHOD}

The design used in this study was Hypothesis Testing, which aimed to examine the influence of online brand trust in increasing purchases during sales promotion. It also aimed to find out certain relationships, or establish differences between groups or the independence of two or more factors in a situation (Sekaran \& Bougie, 2013). Furthermore, a cross-sectional method was used because research and data collection were carried out simultaneously.

Three variables were used, which are, sales promotion, brand trust, and online shopping. A Likert scale was then used to measure the agreement and disagreement of respondents to a series of questions relating to beliefs or behavior about a particular object.

Data collection was carried out by distributing questionnaires to 210 respondents. The samples were selected using non-probability method, i.e., purposive sampling. Furthermore, Structural Equation Modeling (SEM) with AMOS 22 was used as a data analysis technique to test both hypotheses. Before the process, it was necessary to test the model used by holding the goodness of fit model test to ascertain and measure the suitability (Hair et al., 2010).

Furthermore, before analyzing hypotheses, the overall fit models needs to be assessed in advance to ensure it can explain all the cause and effect relationship. As long as one of the criteria for the goodness of fit has been fitted, then the model can be used for the next test.

\section{RESULT AND DISCUSSION}

The results of descriptive statistical calculations of each variable that was explained through the mean and standard deviation are presented in Table 1 below. 
Table 1: Descriptive Statistics of Sales Promotion variables

\begin{tabular}{|c|c|c|}
\hline Indicator (Sales Promotion) & Mean & $\begin{array}{l}\text { Standard } \\
\text { Deviation }\end{array}$ \\
\hline $\begin{array}{l}\text { 1. I prefer to buy products online when available at a packaged price (for } \\
\text { example: purchasing } 2 \text { or more products at a lower price). }\end{array}$ & 4,14 & 0,535 \\
\hline 2. I tend to buy products online due to a discount (e.g., cashback) & 4,10 & 0,522 \\
\hline 3. I consider discounts when shopping & 4,17 & 0,561 \\
\hline $\begin{array}{l}\text { 4. I consider contests when shopping online (e.g., giveaway by fulfilling } \\
\text { several conditions to get an offered prize) }\end{array}$ & 4,07 & 0,575 \\
\hline $\begin{array}{l}\text { 5. I usually do online shopping as long as there is sales promotion (e.g., } \\
\text { cashback, discounts, vouchers, coupons, giveaway, etc). }\end{array}$ & 4,10 & 0,543 \\
\hline $\begin{array}{l}\text { 6. When I open an application and plan to purchase a product, an online } \\
\text { retailer profile display brings up products that I don't really intend to } \\
\text { buy. }\end{array}$ & 4,10 & 0,579 \\
\hline \multicolumn{3}{|l|}{ Indicator (Online Brand Trust) } \\
\hline 1. My personal information and payment mode are protected. & 4,10 & 0,543 \\
\hline 2. My personal information is kept confidential and is not misused. & 4,11 & 0,505 \\
\hline 3. Online brands fulfill their commitment and have a good reputation & 4,11 & 0,529 \\
\hline 4. Friends and relatives also recommended me to shop online. & 4,15 & 0,541 \\
\hline $\begin{array}{l}\text { 5. Online brand websites provide in-depth information to help me shop } \\
\text { online. }\end{array}$ & 4,13 & 0,534 \\
\hline 6. I personally really enjoy online shopping. & 4,20 & 0,522 \\
\hline \multicolumn{3}{|l|}{ Indicator (Online Buying Decision) } \\
\hline $\begin{array}{l}\text { 1. I do online shopping because I can shop without interruption (e.g., } \\
\text { hilarity in the shop or supermarket) }\end{array}$ & 4,22 & 0,529 \\
\hline $\begin{array}{l}\text { 2. I do online shopping because I can shop at any time without having to } \\
\text { leave the house and visit the store. }\end{array}$ & 4,12 & 0,530 \\
\hline $\begin{array}{l}\text { 3. I do online shopping because I can get product information and more } \\
\text { detailed reviews. }\end{array}$ & 4,15 & 0,547 \\
\hline 4. By shopping online, I can compare prices. & 4,15 & 0,589 \\
\hline $\begin{array}{l}\text { 5. I do online shopping to buy products that are not easily available in } \\
\text { offline stores or new (unique) products. }\end{array}$ & 4,15 & 0,532 \\
\hline 6. Online shopping has many benefits for me (cashback and coupons). & 4,15 & 0,532 \\
\hline 7. In my opinion, online shopping suits my lifestyle. & 4,19 & 0,519 \\
\hline $\begin{array}{l}\text { 8. In my opinion, using the Internet for shopping requires consideration } \\
\text { (because I can't see the product directly so purchasing decisions are } \\
\text { very dependent on the reputation of the store or reviews). }\end{array}$ & 4,13 & 0,528 \\
\hline
\end{tabular}

Source: Primary Data, 2019.

The sales promotion variable was measured using 6 statement items. The first item had a mean value of 4.14, which indicated that respondents prefer buying products online when it is available with a price package. This means purchasing 2 or more products together at a lower price. The second has a mean value of 4.10, indicating that respondents tend to buy products online because of discount, i.e., cashback. Furthermore, the third had a mean value of 4.17, meaning that they considered discounts when shopping. The fourth had a mean value of 4.07, which means they consider contests when shopping online, i.e., giveaway to win prizes offered by fulfilling several requirements. Also, the fifth had a mean value of 4.10, meaning that respondents usually shop online as long as there is sales promotion, i.e., cashback, discounts, vouchers, coupons, giveaway, etc. Lastly, the sixth had a mean value of 4.10, which means that when the respondents open an application and plan to purchase a product, the online retailer's profile display products that they don't intend to buy.

Similar to the sales promotion variable, the online brand trust variable was also measured using 6 statement items. The first had a mean value of 4.10, meaning that the respondents' personal information and payment mode are protected. The second had a mean value of 4.11 , which indicates that their 
personal information was kept confidential and not misused. Furthermore, the third had a mean value of 4.11, which showed that respondents hope the online brand fulfills its commitments and have a good reputation. Also, the fourth had a mean value of 4.15, indicating that their friends and relatives recommend shopping online. The fifth had a mean value of 4.13 , which means that brand websites provide in-depth information to help respondents shop. Lastly, the sixth had a mean value of 4.20, which showed that respondents personally enjoyed shopping online.

The online buying decision variable was also measured using 8 statement items. The first had a mean value of 4.22, which means that respondents shop online because they can make purchases without interruption, i.e., hilarity in stores or supermarkets. The second had a mean value of 4.12, indicating that they shop online because they can make purchase at any time without having to leave the house and visit the store. Furthermore, the third had a mean value of 4.15 , which showed that they engage in online shopping because they can get detailed product information and reviews. Also, the fourth had a mean value of 4.15 , which means that by shopping online, respondents can compare prices. The fifth had a mean value of 4.15 , indicating that they shop online to buy products that are not easily available in physical stores or new (unique) products. Furthermore, the sixth had a mean value of 4.15, which showed that online shopping provided many benefits for respondents (cashback and coupons). The seventh had a mean value of 4.19 , which indicated that online shopping is appropriate for the respondents' lifestyle. Lastly, the eighth had a mean value of 4.13 , which showed that using the Internet for shopping requires consideration (because they cannot see the product directly, therefore purchasing decision is highly dependent on the reputation of the store or review).

In this research, Structural Equation Model (SEM) analysis was considered appropriate to be used in testing the hypothesis. According to Sekaran and Bougie (2013), this method can predict changes in the dependent variable, which is associated with changes in the independent type. Meanwhile, the hypothesis refers to previous research conducted by Soni and Verghese (2018).

Based on the results of the first test, it can be concluded that sales promotion has a positive influence on online shopping. Also, it was shown that an increase in promotion in the form of price packages, discounts, vouchers, coupons, giveaway, cashback, etc., makes consumers tend to engage in online shopping. This result supports and is in line with research conducted by Soni and Verghese (2018) that promotion has a positive effect on online shopping.

Table 2: Hypothesis Testing Results

\begin{tabular}{|l|c|c|c|}
\hline \multicolumn{1}{|c|}{ Hypothesis } & Estimate & p-value & Decision \\
\hline $\begin{array}{l}\mathrm{H}_{1} \text { : Sales promotion has a positive influence on online } \\
\text { shopping. }\end{array}$ & 0,809 & 0,000 & $\begin{array}{c}\mathrm{H}_{1} \\
\text { is supported }\end{array}$ \\
\hline $\begin{array}{l}\mathrm{H}_{2 \mathrm{a}} \text { : The effect of sales promotion on online shopping } \\
\text { is stronger for consumers with high brand trust. }\end{array}$ & 0,754 & 0,000 & $\begin{array}{c}\mathrm{H}_{2 \mathrm{a}} \\
\text { is supported }\end{array}$ \\
\hline $\begin{array}{l}\mathrm{H}_{2 \mathrm{~b}} \text { : The effect of sales promotion on online shopping } \\
\text { is stronger for consumers with low brand trust. }\end{array}$ & 0,000 & 0,967 & $\begin{array}{c}\mathrm{H}_{2 \mathrm{~b}} \\
\text { is not supported }\end{array}$ \\
\hline
\end{tabular}

Source: Data processing results, 2019.

Based on the results of the first test, it can be concluded that a relationship occurs between promotion and online shopping which is moderated by brand trust. In testing, it is evident that there are differences between the high and low groups in online trust. When a brand is conducting sales promotion, i.e, discounts, vouchers, giveaway, etc., consumers who have a high level of trust in the brand will be willing to make a purchase (online shopping). These results support and are in line with the research conducted by Soni and Verghese (2018) that moderation of brand trust plays a role in the relationship between sales promotion and Shopping.

Based on the results of the second test, it can also be concluded that there is a relationship between sales promotion and online shopping which is moderated by the brand trust. In the test, it was proven that 
there were differences between the high and low groups in online trust. Meanwhile, consumers with a low level of trust tends to make less purchase even though there is sales promotion, i.e., discounts, vouchers, giveaway, etc,. These results support and are in line with previous studies by Soni and Verghese (2018) that moderating trust plays a role in the relationship between sales promotion and online shopping.

\section{CONCLUSION}

From the results of the analysis and discussion, it can be concluded that sales promotion has a positive influence on online shopping. Furthermore, promotion has a relationship with shopping that is moderated by high brand trusts.

Based on this study, researchers offer suggestions and recommendations for further studies to increase the number of respondents in order to obtain generalized results. Also, other variables that affect online shopping can be included, such as consumer perceptions.

\section{REFERENCES}

Alvarez, B. A., \& Casielles, R. V. (2005). Consumer Evaluations of Sales Promotion: The Effect on Brand Choice. European Journal of Marketing. Vol. 39(1/2), Page.54-70. https://doi.org/10.1108/03090560510572016

Azam, R. (2013). E-Commerce Taxation in China. Journal of Chinese Tax and Policy. Vol. 3, No. 1, Page. 10, February 2013.

Chandon, P., Wansink, B., \& Laurent, G. (2000). A Benefit Congruency Framework of Sales Promotion Effectiveness. Journal of Marketing. Vol 64(4), Page 65-81. https://doi.org/10.1509/jmkg.64.4.65.18071.

Dawson, S., \& Kim, M. (2009). External and Internal Trigger Cues of Impulse Buying Online. Direct Marketing. Vol. 3(1), Page. 20-34.https://doi.org/10.1108/17505930910945714.

Gallagher, K., Foster, K. D., \& Parsons, J. (2001). The Medium is not the Message: Advertising Effectiveness and Content Evaluation in Print and on the Web. Journal of Advertising Research, Vol. 41(4), 57-70.https://doi.org/10.2501/JAR-41-4-57-70

Gong, W., \& Maddox, L. (2011). Online Buying Decisions in China. The Journal of American Academy of Business. Vol. 17, No. 1, Page. 43-55, 2011.

Hair, J. F., Black, W. C., Babin, B. J., \& Anderson, R. E. (2010). Multivariate Data Analysis. Seventh Edition. Prentice Hall. In Exploratory Data Analysis in Business and Economics. https://doi.org/10.1007/978-3-319-01517-0_3

Hassan, L., Shaw, D., Shiu, E., Walsh, G., \& Parry, S. (2013). Uncertainty in Ethical Consumer Choice: A Conceptual Model. Journal of Consumer Behaviour. Vol. 12(3), Page.182-193. https://doi.org/10.1002/cb.1409

Hendrata, Y. kus, Purbandari, T., \& Mujilan (2013). Pengaruh Structural Assurance dan Perceived Reputation terhadap Trust Pengguna Internet di Sistem E-Commerce. Jurnal Riset Manajemen dan Akuntansi.Vol.1.

Hsiao, K. L., Lin, J. C. C., Wang, X. Y., Lu, H. P., \& Yu, H. (2010). Antecedents and Consequences of Trust in Online Product Recommendations: An Empirical Study in Social Shopping. Online Information Review. Vol. 34(6), Page.935-953. https://doi.org/10.1108/14684521011099414

Kenning, P. (2008). The Influence of General Trust and Specific Trust on Buying Behavior. International Journal of Retail and Distribution Management. Vol. 36 No. 6, Page. 461-476. https://doi.org/10.1108/09590550810873938

Kotler \&Keller (2012), Marketing Principles, Twelfth Edition, Volume 1. Jakarta:

Momtaz, N. J., Aghaie, A. \& Alizadeh, S. (2011). Identifying Opinion Leaders for Marketing by Analyzing Online Social Network. International Journal of Virtual Communities and Social Networking, Vol. 3 No. 1, pp. 43-59.

Pathak, B., Garfinkel, R., Gopal, R., Venkatesan, R., \& Yin, F. (2010). Empirical Analysis of the Impact of Recommender Systems on Sales. Journal of Management Information Systems. Vol. (27:2), 2010, Page. 159- 188. https://doi.org/10.2753/MIS0742-1222270205 
Pavlou, P. A., \& Gefen, D. (2004). Building Effective Online Marketplaces with Institution-Based Trust. Information Systems Research. Vol. 15(1) Page.37-59. http://dx.doi.org/10.1287/isre.1040.0015

Pourdehghan, A. (2015). The Impact of Marketing Mix Elements on Brand Loyalty: A Case Study of Mobile Phone Industry. Marketing and Branding Research. Vol. 2, Page. 44- 63. https://doi.org/10.33844/mbr.2015.60184

Satit, R. P., Tat, H. H., Rasli, A., Chin, T. A., \& Sukati, I. (2012). The Relationship between Marketing Mix and Customer Decision-Making over Travel Agents: An Empirical Study. International Journal of Academic Research and Social Science. Vol. 2, No. 6 ISSN: 2222-6990. pp 522-530

Sekaran \& Bougie, R (2013). Research Methods for Business: A Skill-Building Approach. 6th Edition, Wiley, New York.

Siagian, H., \& Cahyono, E. (2014). Analisis Website Quality, Trust dan Loyalty Pelanggan Online Shop. Jurnal Manajemen Pemasaran. Vol. 8, No 2. https://doi.org/10.9744/pemasaran.8.2.55-61

Smith, A. D., \& Rupp, W. T. (2003). Strategic Online Customer Decision Making: Leveraging the Transformational Power of the Internet. Online Information Review. Vol. 27 No. 6, Page. 418432.https://doi.org/10.1108/14684520310510055

Soni, N., \& Verghese, M. (2018). Analyzing the Impact of Online Brand Trust on Sales Promotion and Online Buying Decision. IUP Journal of Marketing Management.

Wang, H., \& Hu, Z. (2009). Online Trust between Inexperienced Consumers and Experienced Consumers: An Empirical Study. 2009 2nd International Conference on Future Information Technology and Management Engineering, FITME 2009. https://doi.org/10.1109/FITME.2009.47

Winch \& Joyce (2006). Exploring the Dynamics of Building, and Losing, Consumer Trust in B2C EBusiness. International Journal of Retail \& Distribution Management.Vol. 34 No. 7, Page. 541555. https://doi.org/10.1108/09590550610673617

Witel (2011). The Antecedents and Consequences of Trust in Online Purchase Decisions. Journal of Interactive Marketing, Vol. 16 (2), Page. 47-63.

Yulihasri, Amir, K. D., Aminul, I. (2011). Factors that Influence Customers' Buying Intention on Shopping Online. International Journal of Marketing Studies, 3(1), 128-139.

Zhou, Z., Zhang, Q., Su, C., \& Zhou, N. (2012). How do Brand Communities generate Brand Relationships? Intermediate Mechanisms. Journal of Business Research. Vol. 65(7): 890-895. https://doi.org/10.1016/j.jbusres.2011.06.034 